\title{
Transcatheter aortic valve replacement valve durability: Good enough for young, low-risk patients?
}

\author{
J. James Edelman, MBBS(Hons), PhD, Christian Shults, MD, and Vinod H. Thourani, MD
}

\footnotetext{
From the Department of Cardiovascular Surgery, Marcus Heart and Vascular Center, Piedmont Heart Institute Atlanta, GA.

Received for publication April 8, 2019; revisions received May 2, 2019; accepted for publication May 4, 2019; available ahead of print Oct 13, 2019.

Address for reprints: Vinod H. Thourani, MD, Department of Cardiovascular Surgery, Piedmont Heart Institute, 95 Collier Road, Suite 5015, Atlanta, GA 20010 (E-mail: vinod.thourani@piedmont.org).

J Thorac Cardiovasc Surg 2020;159:1249-55

$0022-5223 / \$ 36.00$

Copyright (C) 2019 Published by Elsevier Inc. on behalf of The American Association for Thoracic Surgery

https://doi.org/10.1016/j.jtcvs.2019.05.089
}

Feature Editor's Note-In the evolution of transcatheter aortic valve replacement (TAVR) therapy, consider an interesting parallel to the story of coronary angioplasty and stenting. While early critics of percutaneous coronary intervention (PCI) cited concerns of durability and need for repeat revascularization, PCI has evolved to become standard of care in some cases. In others, PCI and surgical bypass are complementary techniques for a total revascularization strategy. Over the years, clinical trial and observational data have come to define the role of each. For aortic valve pathology, TAVR began as a disruptive technology alternative to surgical aortic valve replacement (SAVR) and has rapidly moved to a defined role and benefit in selected patients. However, as in PCI, 1 answer may not fit all.

At the American Association for Thoracic Surgery 99th Annual Meeting and in recent publications, data have been presented from clinical trials for balloon-expandable and self-expanding valves in low-risk patients. ${ }^{1,2}$ Early TAVR trial participants were characterized by short life expectancy, with published results focusing on procedural safety and short-term outcomes. As the eligible patient population changes, our specialty's duty is to safeguard the responsible use of TAVR for the long-term. Accordingly, Edelman and colleagues draw on published data to paint a preliminary picture of TAVR and SAVR durability. This is a timely article because the question is paramount to decision making for low-risk patients and for the question of which therapy-SAVR or TAVR-for which patient.

\section{Richard Lee, MD, MBA}

\section{Dawn S. Hui, MD}

A paradigm shift has occurred in the treatment of aortic stenosis, with transcatheter aortic valve replacement (TAVR) now an established alternative for the treatment of patients at intermediate, high, or extreme risk for surgery. ${ }^{3-7}$ TAVR has now been approved for the treatment

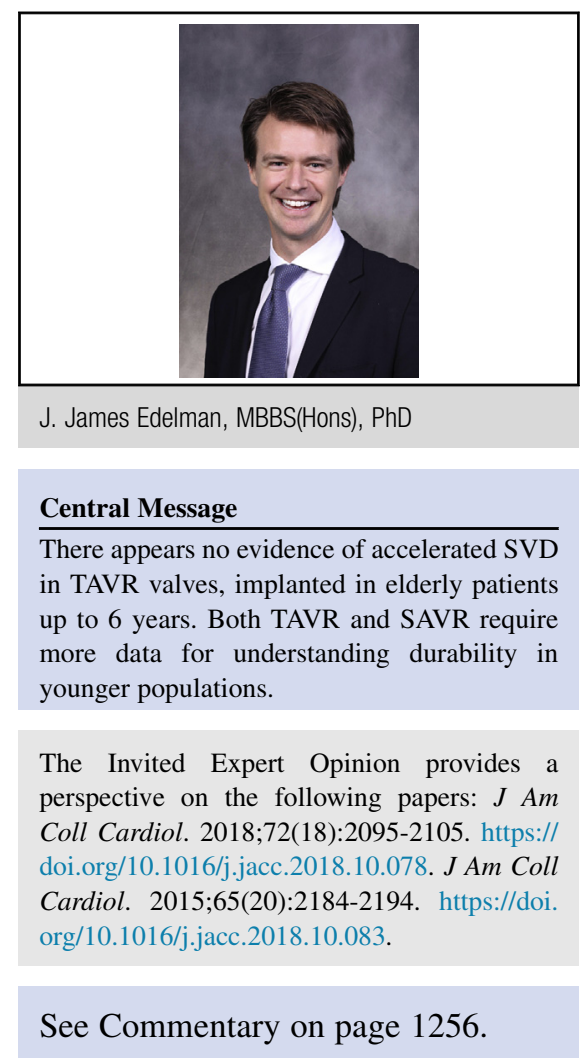

of low-risk patients in the US, after 2 randomized trials comparing TAVR with surgical aortic valve replacement (SAVR) in low-risk patients have shown lower rates of death or stroke at 30 days and no difference at 1 year. $^{1,2}$

The most pressing question as TAVR moves to use in lower-risk, younger patients concerns the technology's durability. The average age of TAVR and SAVR patients was approximately 83 years in the high-risk and 79 to 82 years in the intermediate-risk randomized trials; these patients would not be expected to outlive the durability of their valve bioprosthesis. ${ }^{4-7}$ Patients enrolled in the low-risk trials had an average age of 73 years and with a planned 10-year clinical and echocardiographic follow-up, this should provide valuable information about both TAVR and SAVR durability. ${ }^{1,2}$ Follow-up from high-risk randomized trials comparing TAVR and SAVR have reported 5-year results and a number of other registry sources are now examining valve durability. ${ }^{5,8-13}$ 


\section{PATHOLOGY OF VALVE DETERIORATION}

Bioprostheses typically fail as a result of leaflet calcification that causes stenosis or leaflet tearing leading to regurgitation. Bioprosthetic leaflets are typically fixed in glutaraldehyde to render them immunologically inert, whereas unfixed leaflets undergo an aggressive form of humoral and cellular rejection. ${ }^{14}$ The fixation process is believed to lead to calcification over time, as free-aldehyde groups bind with circulating calcium; leaflet fixation techniques that limit the amount of free-aldehyde groups may potentially decrease calcification. ${ }^{15}$ Increased circulating calcium in renal failure and mechanical stress as a result of patient-prosthesis mismatch (PPM) or hypertension (among other causes) are common mechanisms of leaflet degeneration. Young patients may have accelerated calcification and degeneration, as a result of increased mechanical stresses (due to greater activity and thus cardiac output) and greater immunogenicity and subsequent inflammation compared with an elderly population. ${ }^{16}$ Crimping of the valve leaflets during preparation of TAVR valves causes wrinkling and cracks that are visible with scanning electron microscopy, worse when crimped to $14 \mathrm{~F}$ compared with $18 \mathrm{~F} .{ }^{17}$ Crimped leaflets placed subcutaneously in rats for 12 weeks did not calcify, but exhibited significant fragmentation compared with uncrimped leaflet tissue. ${ }^{18}$ The influence of these microscopic changes on durability is unclear. Reduced leaflet motion due to thrombosis has been identified in both SAVR and TAVR valves, but its relationship with valve durability is similarly unclear. ${ }^{19}$

\section{DEFINITION OF STRUCTURAL VALVE DETERIORATION}

Determination of the durability of surgically placed bioprostheses has been limited by heterogenous definitions of structural valve deterioration (SVD) and a lack of protocolized echocardiographic follow-up. Bioprosthetic valve dysfunction is grouped into 4 categories: SVD, non-SVD (which includes PPM), thrombosis, and endocarditis. ${ }^{20}$ The definitions are detailed in Table 1. Until recently, SVD had been poorly defined and reported. The need for valve reoperation or reoperation due to SVD have been used as surrogate end points, but inherently contribute to an underestimation of true SVD because many patients will be too elderly or frail or refuse to undergo reoperative surgery. The Valve Academic Research Consortium-2 (VARC-2) ${ }^{21}$ and the European Association of Percutaneous Cardiovascular Interventions, European Society of Cardiology, and European Association for Cardio-thoracic Surgery have published a consensus statement on standardized definitions of SVD and valve failure. ${ }^{20}$ These are summarized in Table 2 .

VARC-2 defines valve-related dysfunction as mean aortic gradient $\geq 20 \mathrm{~mm} \mathrm{Hg}$, effective orifice area
TABLE 1. Causes of bioprosthetic valve dysfunction, from the European Consensus Statement of Structural Deterioration and Valve Failure $^{20}$

\begin{tabular}{|c|c|}
\hline $\begin{array}{c}\text { Structural valve } \\
\text { deterioration }\end{array}$ & $\begin{array}{l}\text { Permanent changes to the prosthetic valve, } \\
\text { including calcification, leaflet thrombosis, } \\
\text { tear, or flail that leads to degeneration and/or } \\
\text { hemodynamic dysfunction }\end{array}$ \\
\hline $\begin{array}{l}\text { Nonstructural valve } \\
\text { deterioration }\end{array}$ & $\begin{array}{l}\text { Abnormalities not intrinsic to the valve itself: } \\
\text { paravalvular regurgitation, prosthesis } \\
\text { malposition, patient-prosthesis mismatch, or } \\
\text { late embolization that leads to degeneration of } \\
\text { dysfunction }\end{array}$ \\
\hline Thrombosis & $\begin{array}{l}\text { Thrombus development of any structure of the } \\
\text { prosthetic valve that leads to dysfunction with } \\
\text { or without thromboembolism }\end{array}$ \\
\hline Endocarditis & $\begin{array}{l}\text { Infection involving any structure of the prosthetic } \\
\text { valve, leading to paravalvular abscess, } \\
\text { dehiscence, pseudoaneurysm, fistulae, } \\
\text { vegetation, cusp rupture, or perforation }\end{array}$ \\
\hline
\end{tabular}

$\leq 0.9$ to $1.1 \mathrm{~cm}^{2}$ and/or dimensionless valve index $<0.35$, and/or moderate or severe prosthetic valve deterioration (noting that device success at implantation requires that none of those criteria are met at time of implant). ${ }^{21}$ The European societies' consensus statement defines SVD using either hemodynamic or morphological criteria (or both). ${ }^{20}$ Hemodynamic measures of severe SVD are defined as a mean gradient $\geq 40 \mathrm{~mm} \mathrm{Hg}$ and/or $\geq 20 \mathrm{~mm}$ $\mathrm{Hg}$ change from baseline (before discharge or within 30 days of implantation) and/or severe new or worsening (more than 2 grades) intraprosthetic aortic regurgitation. Morphologic measures include leaflet integrity, structure (thickening/calcification causing stenosis or regurgitation), function (impaired mobility causing stenosis or regurgitation), and strut frame (fracture of failure). The European societies documents recognize that SVD can occur in the absence of clinical symptoms; they recommend the reporting of bioprosthetic valve failure, which integrates the definition of SVD with clinical consequences.

In the European societies' consensus definition, the definition of SVD can include, but does not require, a change from postoperative baseline gradient. This can be problematic should the baseline gradient be $\geq 20 \mathrm{~mm} \mathrm{Hg}$, and may lead to an overestimation of SVD.

\section{SURGICAL AORTIC VALVE DURABILITY}

An increasing number of bioprosthetic surgical valves are being placed in younger patients. This shift in practice, reflected by changes in recommendations by the Valvular Heart Disease Guidelines, ${ }^{22}$ has been driven by improvement in outcomes of reoperation, a recognition of the complications of long-term coagulation and the increasing availability or promise of TAVR valve-in-valve 
TABLE 2. Summary of Valve Academic Research Consortium-2 (VARC-2) and European Consensus Statements for structural valve deterioration

\begin{tabular}{|c|c|c|c|}
\hline Consensus document & Mild & Moderate & Severe \\
\hline \multirow[t]{4}{*}{ VARC- $2^{21}$} & $\begin{array}{l}\text { Peak velocity } 3-4 \mathrm{~m} / \mathrm{s} \\
\text { Mean gradient } 20-40 \mathrm{~mm} \mathrm{Hg} \\
\text { DVI } 0.35-0.25 \\
\text { EOA }>1.1-0.8 \mathrm{~cm}^{2}\left(B S A \geq 1.6 \mathrm{~cm}^{2}\right) \\
\text { EOA } 0.9-0.6 \mathrm{~cm}^{2}\left(B S A<1.6 \mathrm{~cm}^{2}\right)\end{array}$ & $\begin{array}{l}\text { Moderate/severe are combined: } \\
\text { Peak velocity }>4 \mathrm{~m} / \mathrm{s} \\
\text { Mean gradient }>40 \mathrm{~mm} \mathrm{Hg} \\
\text { DVI }<0.25 \\
\text { EOA }<0.8 \mathrm{~cm}^{2}\left(\text { BSA } \geq 1.6 \mathrm{~cm}^{2}\right) \\
\text { EOA }<0.6 \mathrm{~cm}^{2}\left(\text { BSA }<1.6 \mathrm{~cm}^{2}\right)\end{array}$ & \\
\hline & Insignificant & $\begin{array}{l}\text { PPM } 0.85-0.65 \mathrm{~cm}^{2} / \mathrm{m}^{2}(\text { BMI }<30) \\
\text { PPM } 0.90-0.60 \mathrm{~cm}^{2} / \mathrm{m}^{2}(\text { BMI } \geq 30)\end{array}$ & $\begin{array}{l}\text { PPM }<0.65 \mathrm{~cm}^{2} / \mathrm{m}^{2}(\text { BMI }<30) \\
\text { PPM }<0.60 \mathrm{~cm}^{2} / \mathrm{m}^{2}(\text { BMI } \geq 30)\end{array}$ \\
\hline & $\begin{array}{l}\text { Absent of brief diastolic flow reversal } \\
\text { in descending aorta } \\
\text { Circumferential extent of } \\
\text { paravalvular regurgitation }<10 \%\end{array}$ & $\begin{array}{l}\text { Intermediate diastolic flow reversal in } \\
\text { descending aorta } \\
\text { Circumferential extent of } \\
\text { paravalvular regurgitation } \\
10 \%-29 \%\end{array}$ & $\begin{array}{l}\text { Prominent holodiastolic flow reversal } \\
\text { in descending aorta } \\
\text { Circumferential extent of } \\
\text { paravalvular regurgitation } \geq 30 \%\end{array}$ \\
\hline & $\begin{array}{l}\text { Regurgitant volume }<30 \mathrm{~mL} / \text { beat } \\
\text { Regurgitant fraction }<30 \% \\
\text { EROA } 0.10 \mathrm{~cm}^{2}\end{array}$ & $\begin{array}{l}\text { Regurgitant volume } 30-59 \mathrm{~mL} / \mathrm{beat} \\
\text { Regurgitant fraction } 30 \%-49 \% \\
\text { EROA } 0.10-0.29 \mathrm{~cm}^{2}\end{array}$ & $\begin{array}{l}\text { Regurgitant volume } \geq 60 \mathrm{~mL} / \text { beat } \\
\text { Regurgitant fraction } \geq 50 \% \\
\text { EROA } \geq 0.30 \mathrm{~cm}^{2}\end{array}$ \\
\hline European Consensus $^{22}$ & $\begin{array}{l}\text { Not defined: Thought to be of less } \\
\text { clinical importance }\end{array}$ & $\begin{array}{l}\text { i) Mean gradient } \geq 20 \text { and }<40 \mathrm{~mm} \\
\mathrm{Hg} \text { and/or } \geq 10 \mathrm{~mm} \mathrm{Hg} \text { and } \\
<20 \mathrm{~mm} \mathrm{Hg} \text { change from baseline } \\
\text { (before discharge or within } 30 \mathrm{~d} \text { ) } \\
\text { ii) Moderate new or worsening } \\
(>1+/ 4+\text { ) intra-prosthetic aortic } \\
\text { regurgitation }\end{array}$ & $\begin{array}{l}\text { i) Mean gradient } \geq 40 \mathrm{~mm} \mathrm{Hg} \text { and /or } \\
\geq 20 \mathrm{~mm} \mathrm{Hg} \text { change from baseline } \\
\text { ii) Severe new or worsening ( }>2+/ \\
4+\text { ) intra-prosthetic aortic } \\
\text { regurgitation }\end{array}$ \\
\hline
\end{tabular}

European Consensus Morphological Criteria for SVD (any of the following):

- Leaflet integrity abnormality (ie, torn or flail causing intraframe regurgitation)

- Leaflet structure abnormality (ie, pathological thickening and/or calcification causing valvular stenosis or central regurgitation)

- Leaflet function abnormality (ie, impaired mobility resulting in stenosis and/or central regurgitation

- Strut/frame abnormality (ie, fracture)

$D V I$, Dimensionless valve index; $E O A$, effective orifice area; $B S A$, body surface area; $P P M$, prosthesis-patient mismatch; $B M I$, body mass index; $E R O A$, effective regurgitant orifice area; $S V D$, structural valve deterioration.

(ViV), but has occurred without the support of evidence of a mortality benefit compared with mechanical valves, or evidence of improved durability of bioprostheses.

There remains limited detailed understanding of the durability of surgically placed bioprostheses. Durability has until recently been measured in the majority of studies by reintervention due to SVD, rather than regular protocol-driven clinical and echocardiographic follow-up. A number of single-center studies have been well conducted, and are particularly informative.

David and colleagues ${ }^{23}$ prospectively followed 1134 patients undergoing SAVR with the Hancock II bioprosthesis (Medtronic; Minneapolis, Minn). Patch annular enlargements were performed in $19 \%$ of patients. Mean age at implant was 67 years, follow-up was for a median of 12.2 years, and was $99.2 \%$ complete. Multiple echocardiograms were available in $94 \%$ of patients. SVD was defined by echocardiographic indications for reoperation. SVD occurred in 87 patients $(7.6 \%), 74$ underwent reoperation; an additional 30 patients underwent reoperation for other indications, such as endocarditis, dissection, aneurysm, and others. Age was the only independent predictor of SVD. Freedom from SVD was $99.8 \%$ at 10 years in patients aged $>70$ years, $89.5 \%$ in patients aged $<60$ years. Beyond 10 years in patients aged $<60$ years at the time of implant, SVD increases significantly, with only $65 \%$ free of SVD at 15 years.

Johnston and colleagues ${ }^{24}$ evaluated 12,569 patients undergoing aortic valve replacement with an Perimount (Edwards Lifesciences, Irvine, Calif) prosthesis at mean age 71 years, between 1982 and 2011. Of 354 prostheses explanted, $44 \%$ were due to SVD, another $41 \%$ due to endocarditis, and the remainder due to other reasons (valve thrombosis occurred in $<1 \%$ ). Median follow-up was 5.8 years and $87 \%$ complete; $25 \%$ were followed to 10 years, $5 \%$ were followed to 15 years. Median echocardiographic follow-up time was 1.3 months; $25 \%$ were followed for more than 2.8 years, and $5 \%$ were followed for more than 9.4 years. For patients younger than age 60 years, 10-year estimate for risk of explant was $5.6 \%$ and $20 \%$ at 15 years. For patients aged 60 to 80 years at implant, estimates for risk of explant was $5.1 \%$ and $8.1 \%$ at 10 years and 15 years, respectively. There were no explant events for SVD in patients older 
than age 80 years. Age, lipid-lowering drugs, PPM, and high postoperative gradients were predictors of need for explant.

Bourguignon and colleagues ${ }^{25}$ followed 516 patients undergoing SAVR with Carpentier-Edwards Perimount bioprostheses aged 50 to 65 years between 1984 and 2008. Patients had an annual echocardiogram and clinical assessment by questionnaire. Mean follow-up was 9.6 years and $97 \%$ complete. SVD (defined as mean gradient $\geq 40 \mathrm{~mm} \mathrm{Hg}$ or severe aortic regurgitation) was reported in 81 patients, 70 of whom underwent redo valve replacement or TAVR at mean 13.5 years after initial SAVR. Actuarial freedom from SVD was $90 \%$ at 10 years and $72 \%$ at 15 years. These bioprostheses were placed in patients with contraindication to warfarin, endocarditis, or multiple comorbidities; that is, those who would not be expected to outlive their valve. The rate of SVD may be underestimated.

In 564 patients (mean age 74 years, annual echocardiogram follow-up, $97 \%$ complete) with an aortic valve bioprosthesis, Flameng and colleagues $^{26}$ demonstrated PPM and valve size $<21 \mathrm{~mm}$ to be independent predictors of SVD. In patents without PPM, SVD did not occur until 9 years; in those with PPM, SVD began to occur after 2 to 3 years.

The aforementioned studies provide reassurance in terms of durability of the 2 bioprosthetic valves studied in the medium to long term. Some valves had been associated with excellent durability at 5 years, only to have accelerated SVD between 5 and 10 years. ${ }^{27}$ In the Valve-in-Valve International Data Registry, examining placement of TAVR prostheses in failed surgical prostheses, the mean duration of time between surgery and TAVR ViV was 9 years. Patients were aged 77 years at time of ViV TAVR. There are unfortunately few prospective studies with complete follow-up to guide valve choice. Until recently, the majority of bioprostheses were placed in elderly patients or those not expected to have a long life expectancy (albeit at a younger age than even those in the low-risk TAVR trials), which may have influenced surgical durability results. With the change in recommendations regarding valve choice, we have an opportunity to better understand valve durability as more young, healthy patients have bioprostheses implanted. ${ }^{22}$ This will require prospective study with regular echocardiographic follow-up.

\section{TRANSCATHETER AORTIC VALVE DURABILITY}

The durability of TAVR has not yet been tested given its initial introduction into the elderly prohibitive- and high-risk populations. The Society of Thoracic Surgeons/ American College of Cardiology Transcatheter Valve Therapy Registry identified $2.5 \%$ of patients with an increase in mean gradient $\geq 10 \mathrm{~mm} \mathrm{Hg}$ in 2 consecutive echocardiograms at 1 year; predictors of increase included small valve implant, ViV procedure, or PPM. ${ }^{28}$ Male sex, body mass index, and chronic lung disease were other patient factors. A number of trials and registries have reported up to 6 years' follow-up (Table 3). None of the registries signal a red flag warning about TAVR durability, compared with SAVR, albeit in an elderly population in whom it is expected that the rate of SVD is low.

The Nordic Aortic Valve Intervention study was the first to compare TAVR (self-expanding valves) and SAVR in low-risk patients with average age 79 years; the study has recently reported durability outcomes with 5 years' follow-up (6 years in 50 TAVR and 50 SAVR patients). ${ }^{13}$ Patients had annual echocardiograms performed at individual sites (there was no central core laboratory for standardization). The study used a definition consistent with the European Association of Percutaneous Cardiovascular Interventions, European Society of Cardiology, and European Association for Cardio-thoracic Surgery consensus statement. Because 9 SAVR (and 1 TAVR) patients had gradients $\geq 20 \mathrm{~mm} \mathrm{Hg}$ at 3 months' follow-up they modified the definition to include both mean gradient $\geq 20 \mathrm{~mm} \mathrm{Hg}$ and an increase in $10 \mathrm{~mm} \mathrm{Hg}$ since 3-month follow-up. This was achieved in $12.4 \%$ of SAVR and $1.4 \%$ TAVR patients $(P<.001)$ (SAVR $24 \%$ vs $4.8 \%[P<.001]$ without the modification). Non-SVD or bioprosthetic valve failure (the integration of SVD and clinical consequences) did not differ between TAVR and SAVR. TAVR patients had more paravalvular regurgitation (TAVR $20.9 \%$ vs SAVR $1.5 \%[P<.0001]$, but less severe PPM at 3 months (TAVR $12.2 \%$ vs SAVR $28.1 \%$ $[P=.001])$. Rates of valve-related death, reintervention, severe hemodynamic SVD, and endocarditis did not differ. Placement of small valve sizes are the most likely explanation for the higher rate of SVD (a 19-mm or 21-mm SAVR prosthesis was used in 39\%), recognizing that surgeons are more likely to prioritize a shorter duration of crossclamp and cardiopulmonary bypass rather than a root enlargement procedure in an elderly population. A Mitroflow (LivaNova, London, United Kingdom) prosthesis, recognized to have early valve degeneration beyond 5 years, was used in $10 \%$ of SAVR patients ${ }^{27}$; however, rates of SVD for individual prostheses were not reported.

Mack and colleagues ${ }^{5}$ reported 5-year follow-up of the Placement of Aortic Transcatheter Valve 1 trial, comparing TAVR (balloon-expandable valves) and SAVR in a high-risk operable cohort of patients with mean age 84 years. These was no difference in valve hemodynamics between TAVR and SAVR; only $32 \%$ of patients were alive at time of follow-up and $<20 \%$ of the population were "at risk" or available for inclusion for mortality estimates at 5 years. There was only slight hemodynamic change in TAVR valves over 5 years' 
TABLE 3. Transcatheter aortic valve replacement (TAVR) durability trials

\begin{tabular}{|c|c|c|c|c|c|c|}
\hline Trial & $\mathbf{N}$ & $\begin{array}{l}\text { Mean } \\
\text { age }(y)\end{array}$ & Follow-up & $\begin{array}{c}\text { Alive at } \\
\text { follow-up }(\%)\end{array}$ & Valve type & Durability outcome \\
\hline $\begin{array}{l}\text { Placement of Aortic } \\
\text { Transcatheter } \\
\text { Valve } 1^{3,29}\end{array}$ & 348 & 84 & $5 y$ & 32 & $\begin{array}{l}\text { Edwards Sapien } \\
\text { (Edwards Lifesciences, } \\
\text { Irvine, CA) }\end{array}$ & $\begin{array}{l}\text { - SVD requiring SAVR } 0 \% \\
\text { - VARC-2 severe SVD } 0.5 \% \\
\text { - Moderate/severe intra-prosthetic } \\
\text { AR } 3.7 \%\end{array}$ \\
\hline $\begin{array}{l}\text { CoreValve US } \\
\text { Pivotal Trial }^{8}\end{array}$ & 391 & 83 & $5 y$ & 45 & $\begin{array}{l}\text { Medtronic Corevalve } \\
\text { (Medtronic, } \\
\text { Minneapolis, MN) }\end{array}$ & $\begin{array}{l}\text { - Moderate SVD } 9.2 \% \\
\text { - Severe SVD } 0.8 \% \\
\text { - Moderate/severe intra-prosthetic } \\
\text { AR } 3.6 \%\end{array}$ \\
\hline $\begin{array}{l}\text { Barbanti and } \\
\text { colleagues }{ }^{10} \\
\text { (8 Italian centers) }\end{array}$ & 353 & 82 & $5 \mathrm{y}$ & 45 & $\begin{array}{l}\text { Third generation } \\
\text { Medtronic } \\
\text { Corevalve }\end{array}$ & $\begin{array}{l}\text { - Slight increase in gradient at } 5 \mathrm{y} \\
(\mathrm{n}=108) \text { from } 10 \text { to } 13 \mathrm{~mm} \mathrm{Hg} \\
\text { - } 15 \text { patients had valve failure or } \\
\text { gradient } 20-40 \mathrm{~mm} \mathrm{Hg}\end{array}$ \\
\hline $\begin{array}{l}\text { Corevalve } \\
\text { ADVANCE } \\
\text { study }^{11}\end{array}$ & 996 & 81 & $5 y$ & 49.3 & Medtronic Corevalve & $\begin{array}{l}\text { - } 9.3 \% \text { (of } 267 \text { patients) had gradient } \\
\text { increase }>50 \% \\
\text { - } 2.6 \% \text { valve dysfunction per } \\
\text { VARC-2 } \\
\text { - } 1.8 \% \text { endocarditis (of } 996 \text { patients) }\end{array}$ \\
\hline $\begin{array}{l}\text { UK Transcatheter } \\
\text { Aortic Valve } \\
\text { Implantation } \\
\text { Registry }^{12}\end{array}$ & 241 & 79 & $5.8 \mathrm{y}$ & $\begin{array}{l}100 \% \text { (paired } \\
\text { postprocedure } / 5 \text { y } \\
\text { echocardiogram to } \\
\text { be eligible for } \\
\text { study) }\end{array}$ & $\begin{array}{l}65 \% \text { Self-expanding } \\
\text { valve } \\
35 \% \text { Balloon- } \\
\quad \text { expandable valve }\end{array}$ & $\begin{array}{l}\text { - Lower mean peak gradient baseline } \\
\text { to flu (19 to } 17 \mathrm{~mm} \mathrm{Hg} \text { ) } \\
\text { - } 1 \text { case severe SVD } \\
\text { - } 21 \text { cases moderate SVD (European } \\
\text { definition) } \\
\text { - No valve degeneration in ViV } \\
\text { TAVR patients }\end{array}$ \\
\hline $\begin{array}{l}\text { Nordic Aortic } \\
\text { Valve } \\
\text { Intervention }^{13}\end{array}$ & 139 & 79 & $\begin{array}{l}5 \mathrm{y} \text { (6 y in } \\
50 \text { patients) }\end{array}$ & 57.5 & $\begin{array}{l}\text { Medtronic } \\
\text { CoreValve }\end{array}$ & $\begin{array}{l}\text { - SVD } 4.8 \% \text { (moderate/severe by } \\
\text { European definition) } \\
\text { - NSVD } 53 \% \text { ( } 43 \% \text { PPM, } 22 \% \\
\text { PVR) } \\
\text { - Endocarditis } 5.8 \% \\
\text { - } \text { BVF } 7.5 \% \\
\text { - } \text { Reintervention } 2.2 \%\end{array}$ \\
\hline $\begin{array}{c}\text { Toggweiler and } \\
\text { colleagues }^{9}\end{array}$ & 88 & 83 & $5 y$ & 35 & $\begin{array}{l}\text { Cribier-Edwards } \\
\quad \text { (Edwards Lifesciences, } \\
\text { Irvine, CA) } \\
\text { Edwards Sapien }\end{array}$ & $\begin{array}{l}\text { - } 3 \text { of } 29 \text { Surviving patients had } \\
\text { moderate SVD at } 5 \mathrm{y} \text {; } \\
\text { - } \geq \text { Moderate PVR predictor of } \\
\text { mortality }\end{array}$ \\
\hline
\end{tabular}

$S V D$, Structural valve deterioration; $S A V R$, surgical aortic valve replacement; $V A R C$-2. Valve Academic Research Consortium-2; $A R$, aortic regurgitation; ViV, valve in valve; $N S V D$, nonstructural valve deterioration; $P P M$, patient-prosthesis mismatch; $P V R$, paravalvular regurgitation; $B V F$, bioprosthetic valve failure.

follow-up (mean, 9.2-10.1 $\mathrm{mm} \mathrm{Hg}$ ), that included the Placement of Aortic Transcatheter Valve 1 trial inoperable cohort and continued access registry. ${ }^{29}$ Nearly half of TAVR and SAVR patients achieved the VARC-2 definition of mild stenosis, but very few achieved the definition of severe stenosis with a gradient $\geq 40 \mathrm{~mm} \mathrm{Hg}$. Moderate or severe transvalvular aortic regurgitation developed in $3.7 \%$ of TAVR patients and $0.6 \%$ of SAVR patients (none severe). Because aortic regurgitation was a mechanism of valve deterioration in $60 \%$ (the primary mechanism in $30 \%$ ) of $\mathrm{ViV}$ reinterventions in the Valvein-Valve International Data Registry, the development of aortic regurgitation requires careful surveillance. ${ }^{30}$ Among patients who died at follow-up in the Placement of Aortic Transcatheter Valve 1 trial, those who underwent 2 consecutive echocardiograms before death, an increase in gradient $>10 \mathrm{~mm} \mathrm{Hg}$, or dimensionless valve index $<0.25$ was rare. ${ }^{31}$

At 5-year follow-up in the high-risk CoreValve Pivotal trial, $9.2 \%$ of TAVR patients $(26.6 \%$ SAVR patients $)$ achieved moderate SVD, the majority due to a gradient between 20 and $40 \mathrm{~mm} \mathrm{Hg}$ or new moderate transvalvular aortic regurgitation; only $0.8 \%$ of TAVR patients (1.7\% SAVR patients) achieved severe SVD. ${ }^{8}$

The UK Transcatheter Aortic Valve Implantation Registry has reported outcomes of 241 patients, mean age 
79 years, who had paired postprocedure baseline and $\geq 4.5$ years' follow-up (mean, 5.8 years), using European consensus definitions. Sixty-five percent of valves were self-expanding and $35 \%$ were balloon expandable. Only 1 patient had severe SVD (severe aortic regurgitation at 5.3 years). Moderate SVD was present in $8.7 \%$; in approximately $60 \%$ the primary mechanism was aortic regurgitation. Mean gradients did not increase over time and the results were excellent for the majority of patients. Just as other trials are potentially biased by having a very low number of patients included in longer-term follow-up, the inclusion of patients only with paired follow-up selects those who are more likely to have had good outcomes with TAVR and may overestimate success. It nonetheless supports good TAVR durability in this population.

\section{GOOD ENOUGH? ASSESSING DURABILITY IN YOUNG, LOW-RISK PATIENTS}

TAVR in low-risk patients was approved in the US in August, 2019. The major trials in low-risk patients have included patients aged in their mid-70 years and follow-up is limited to 12 months. To date with this limited data, there appears to be no difference in SVD between TAVR and SAVR. TAVR valves are certainly very safe in the short term, but whether they will remain durable in the longer term is not yet clear. We now have available some data of TAVR durability of up to 6 years; however, experience from the surgical series suggests that this medium-term data are not yet long enough for the youngest of patients receiving bioprosthetic TAVR or SAVR valves. Given the association between PPM and accelerated SVD, it is important that surgeons and TAVR teams implant the largest possible bioprostheses.

The consensus definitions of SVD are important to better understand the durability of bioprosthetic valves, be they implanted surgically or transcatheter. The integration of clinical symptoms and events with echocardiographic changes in complete cohorts of prospectively followed patients will be the key to answering the question. We must remain vigilant in the assessment of both TAVR and SAVR bioprosthetic prostheses in young patients. These data will most likely come from the randomized trials comparing TAVR and SAVR and (hopefully) from experience placing more surgical bioprostheses in young patients over the coming decade.

\section{CONCLUSIONS}

In the trials and registries available to date, there appears to be no evidence of accelerated SVD in TAVR valves implanted in elderly patients up to 6 years. Given the increasing trend for bioprostheses rather than mechanical prostheses in SAVR, and the introduction of TAVR for lower-risk patients, both TAVR and SAVR require more data for understanding valve durability in younger populations.

\section{Conflict of Interest Statement}

Dr Thourani has been an advisor and researcher for Abbott Vascular, Boston Scientific, Edwards Lifesciences, Gore Vascular, and Jenavalve. All other authors have nothing to disclose with regard to commercial support.

\section{References}

1. Mack MJ, Leon MB, Thourani VH, Makkar R, Kodali SK, Russo M, et al. Transcatheter aortic-valve replacement with a balloon-expandable valve in low-risk patients. N Engl J Med. 2019;380:1695-705.

2. Popma JJ, Deeb GM, Yakubov SJ, Mumtaz M, Gada H, O’Hair D, et al. Transcatheter aortic-valve replacement with a self-expanding valve in low-risk patients. N Engl J Med. 2019;380:1695-705.

3. Thourani VH, Kodali S, Makkar RR, Herrmann HC, Williams M, Babaliaros V, et al. Transcatheter aortic valve replacement versus surgical valve replacement in intermediate-risk patients: a propensity score analysis. Lancet. 2016;387: 2218-25.

4. Leon MB, Smith CR, Mack MJ, Makkar RR, Svensson LG, Kodali SK, et al. Transcatheter or surgical aortic-valve replacement in intermediate-risk patients. N Engl J Med. 2016;374:1609-20.

5. Mack MJ, Leon MB, Smith CR, Miller DC, Moses JW, Tuzcu EM, et al. 5-year outcomes of transcatheter aortic valve replacement or surgical aortic valve replacement for high surgical risk patients with aortic stenosis (PARTNER 1): a randomised controlled trial. Lancet. 2015;385: 2477-84.

6. Adams DH, Popma JJ, Reardon MJ, Yakubov SJ, Coselli JS, Deeb GM, et al. Transcatheter aortic-valve replacement with a self-expanding prosthesis. N Engl J Med. 2014;370:1790-8.

7. Reardon MJ, Van Mieghem NM, Popma JJ, Kleiman NS, Søndergaard L, Mumtaz M, et al. Surgical or transcatheter aortic-valve replacement in intermediate-risk patients. N Engl J Med. 2017;376:1321-31.

8. Gleason TG, Reardon MJ, Popma JJ, Deeb GM, Yakubov SJ, Lee JS, et al. Self-expanding transcatheter aortic valve replacement or surgical valve replacement in high-risk patients: 5-year outcomes. J Am Coll Cardiol. 2018; 72:2687-96.

9. Toggweiler S, Humphries KH, Lee M, Binder RK, Moss RR, Freeman M, et al. 5-year outcome after transcatheter aortic valve implantation. J Am Coll Cardiol. 2013;61:413-9.

10. Barbanti M, Petronio AS, Ettori F, Latib A, Bedogni F, De Marco F, et al. 5-Year outcomes after transcatheter aortic valve implantation with CoreValve prosthesis. JACC Cardiovasc Interv. 2015;8:1084-91.

11. Gerckens U, Tamburino C, Bleiziffer S, Bosmans J, Wenaweser P, Brecker S, et al. Final 5-year clinical and echocardiographic results for treatment of severe aortic stenosis with a self-expanding bioprosthesis from the ADVANCE Study. Eur Heart J. 2017;38:2729-38.

12. Blackman DJ, Saraf S, MacCarthy PA, Myat A, Anderson SG, Malkin CJ, et al. Long-term durability of transcatheter aortic valve prostheses. J Am Coll Cardiol. 2019;73:537-45.

13. Søndergaard L, Ihlemann N, Capodanno D, Jørgensen TH, Nissen H, Kjeldsen BJ, et al. Durability of transcatheter and surgical bioprosthetic aortic valves in patients at lower surgical risk. J Am Coll Cardiol. 2019;73: 546-53.

14. Song Z, Zhang J, Bennet W, Wennberg L. Tacrolimus inhibits discordant islet xenograft rejection: a study in the pig-to-rat model. Xenotransplantation. 2003;10:628-34.

15. Flameng W, Hermans H, Verbeken E, Meuris B. A randomized assessment of an advanced tissue preservation technology in the juvenile sheep model. J Thorac Cardiovasc Surg. 2015;149:340-5.

16. Manji RA, Zhu LF, Nijjar NK, Rayner DC, Korbutt GS, Churchill TA, et al Glutaraldehyde-fixed bioprosthetic heart valve conduits calcify and fail from xenograft rejection. Circulation. 2006;114:318-27.

17. Alavi SH, Groves EM, Kheradvar A. The effects of transcatheter valve crimping on pericardial leaflets. Ann Thorac Surg. 2014;97:1260-6.

18. Kiefer P, Gruenwald F, Kempfert J, Aupperle H, Seeburger J, Mohr FW, et al. Crimping may affect the durability of transcatheter valves: an experimental analysis. Ann Thorac Surg. 2011;92:155-60.

19. Makkar RR, Fontana G, Jilaihawi H, Chakravarty T, Kofoed KF, de Backer O, et al. Possible subclinical leaflet thrombosis in bioprosthetic aortic valves. N Engl J Med. 2015;373:2015-24. 
20. Capodanno D, Petronio AS, Prendergast B, Eltchaninoff H, Vahanian A, Modine T, et al. Standardized definitions of structural deterioration and valve failure in assessing long-term durability of transcatheter and surgical aortic bioprosthetic valves: a consensus statement from the European Association of Percutaneous Cardiovascular Interventions (EAPCI) endorsed by the European Society of Cardiology (ESC) and the European Association for Cardio-Thoracic Surgery (EACTS). Eur Heart J. 2017;38:3382-90.

21. Kappetein AP, Head SJ, Généreux P, Piazza N, Van Mieghem NM, Blackstone EH, et al. Updated standardized endpoint definitions for transcatheter aortic valve implantation: the valve academic research consortium-2 consensus document. Eur Heart J. 2012;33:2403-18.

22. Nishimura RA, Otto CM, Bonow RO, Carabello BA, Erwin JP, Fleisher LA, et al. 2017 AHA/ACC focused update of the 2014 AHA/ACC guideline for the management of patients with valvular heart disease: a report of the American College of Cardiology/American Heart Association task force on clinical practice Guidelines. Circulation. 2017;135:e1159-95.

23. David TE, Armstrong S, Maganti M. Hancock II bioprosthesis for aortic valve replacement: the gold standard of bioprosthetic valves durability? Ann Thorac Surg. 2010;90:775-81.

24. Johnston DR, Soltesz EG, Vakil N, Rajeswaran J, Roselli EE, Sabik JF, et al. Long-term durability of bioprosthetic aortic valves: implications from 12,569 implants. Ann Thorac Surg. 2015;99:1239-47.
25. Bourguignon T, Lhommet P, El Khoury R, Candolfi P, Loardi C, Mirza A, et al Very long-term outcomes of the Carpentier-Edwards Perimount aortic valve in patients aged 50-65 years. Eur J Cardiothorac Surg. 2016;49:1462-8.

26. Flameng W, Herregods M-C, Vercalsteren M, Herijgers P, Bogaerts K, Meuris B Prosthesis-patient mismatch predicts structural valve degeneration in bioprosthetic heart valves. Circulation. 2010;121:2123-9.

27. Ius F, Schulz J, Roumieh M, Fleissner F, Ismail I, Tudorache I, et al. Long-term results of the Mitroflow aortic pericardial bioprosthesis in over 800 patients: limited durability and mechanisms of dysfunction. Eur J Cardiothorac Surg. 2017;52:264-71.

28. Vemulapalli S, Holmes DR Jr, Dai D, Matsouaka R, Mack MJ, Grover FL, et al. Valve hemodynamic deterioration and cardiovascular outcomes in TAVR: a report from the STS/ACC TVT registry. Am Heart J. 2018;195:1-13.

29. Douglas PS, Leon MB, Mack MJ, Svensson LG, Webb JG, Hahn RT, et al Longitudinal hemodynamics of transcatheter and surgical aortic valves in the PARTNER trial. JAMA Cardiol. 2017;2:1197-206.

30. Dvir D, Webb JG, Bleiziffer S, Pasic M, Waksman R, Kodali S, et al Transcatheter aortic valve implantation in failed bioprosthetic surgical valves JAMA. 2014;312:162.

31. Daubert MA, Weissman NJ, Hahn RT, Pibarot P, Parvataneni R, Mack MJ, et al. Long-term valve performance of TAVR and SAVR. JACC Cardiovasc Imaging. 2017; 10:15-25. 